\begin{tabular}{|c|c|c|}
\hline$\bigvee_{\text {INESEG }}$ & $\begin{array}{c}\text { International Journal of Health Services } \\
\text { Research and Policy }\end{array}$ & \\
\hline $\begin{array}{l}\text { INTERNATIONAL } \\
\text { ENGINEERING }\end{array}$ & www.dergipark.org.tr/ijhsrp & \\
\hline $\begin{array}{c}\text { SCIENCE AND } \\
\text { EDUCATION GROUP }\end{array}$ & e-ISSN: 2602-3482 & IJHSRP \\
\hline
\end{tabular}

Case Report

\title{
PLANNING NURSING CARE OF AN INDIVIDUAL DIAGNOSED WITH COVID-19 ACCORDING TO WATSON'S THEORY OF HUMAN CARING: A CASE REPORT
}

\author{
Safiye YANMIŞ ${ }^{1}$ (1) Yasemin ÖZYER $*^{2}$ (1) \\ ${ }^{1}$ Erzincan Binali Yıldırım University, Fac. of Health Sciences, Dept. of Internal Disease, Erzincan, TURKEY \\ ${ }^{2}$ Sinop University, Durağan Vocational School, Medical Services and Technics Department, Emergency \\ Program, Sinop, TURKEY \\ *Corresponding author: yozyer@ sinop.edu.tr
}

\begin{abstract}
COVID-19 pandemic is a global health crisis defining our age. As a result of the uncontrollable stress in individuals diagnosed with COVID-19, individuals show avoidance behaviours and as a result, the patient restricts their behaviours to a great extent. Intense anxiety worry and uncertainty individuals experience cause them to give different reactions and lead to deterioration in their quality of life. It is essential for nurses working in this challenging process to provide remedial care to individuals by supporting faith, trust, and hope. In this case report, nursing care was planned and applied to a 55-year-old COVID-19 diagnosed female patient who was married with three children according to Watson's Theory of Human Caring. While providing care to the patient, the concepts of faith, hope, and trust were supported by taking into consideration the emotional, spiritual, and physical needs of the patient. The patient was encouraged to express her negative and positive feelings for the disease and her fears and worries were reduced. It was found that nursing care interventions created with Watson's Theory of Human Caring reduced the patient's fears, made communication stronger, and supported faith and hope.
\end{abstract}

Keywords: COVID-19, SARS-CoV-2, Theory of Human Caring, Nursing, Nursing Care.

Received: June 15, $2020 \quad$ Accepted: January 25, 2021

\section{Introduction}

Coronavirus disease 2019 (COVID-19) pandemic, caused by the severe acute respiratory syndrome coronavirus 2 (SARS-CoV-2) virus which appeared in the province of Wuhan, the Hubei state of China on December 31,2019, spread quickly to 6 continents and hundreds of countries and passed into history as the first pandemic caused by coronavirus [1-2]. COVID-19 is mainly transmitted by droplets and by the contact of the disease agent to the mucous membrane after contact with the droplets on surfaces as a result of coughing or sneezing. While the disease is mostly transmitted through sick people, asymptomatic cases also play a critical role in the spread of the disease [3]. The epidemic process, which started in Turkey on March 10, 2020, with the identification of the first positive case, is continuing to increase its impact. As of April 14, 2020, the number of SARS-CoV-2 positive cases is 64.111 and the number of deaths due to disease is 1.403 [3]. Considering the fact that Covid-19 has a 
high power to spread and poses a life threat, this situation may cause fear and high anxiety in individuals [6-9]. The reason why people worry and panic is that they are exposed to an epidemic or the fact that their possibility of getting infected with the virus creates a big threat to them [3]. During the pandemic period, the emergence of situations such as disruption of routine life, sudden change of people's regular, loss of expectations and goals, and disruption or delay of plans cause a traumatic perception on patients [3]. Intense anxiety worry and uncertainty individuals experience cause them to give different reactions and lead to deterioration in their quality of life [6-9].

While developing the Theory of Human Caring, Jean Watson grounded her theory on care and she aimed to find out the contributions of nurses to individuals and society since nursing is a profession that provides care, it is effective in the fields of education and practice and it has high humanistic and moral sensitivity [10]. Model of Human Caring (MHC) focuses on spiritual care which consists of science and art and the essence of nursing is care. During the process of interpersonal care, nurses use healing processes and provide care.

Nurses focus on cognitive, intuitive, and sensory aspects of individuals during care and show that care does not consist only of invasive procedures but also aims to know the individual spiritually and to perceive the individual correctly [10]. Nurses' helpful, supportive, caring, sincere, honest, understanding, and sensitive care behaviours form the basis of the MHC consists of three basic concepts as interpersonal care relationship, the status of care, and the process of treatment [11-12].

This study includes planning, implementation, and evaluation of nursing care according to the patient who was receiving treatment for COVID-19. Watson's MHC supports individualized and holistic care by providing care to the patient in theoretical, philosophical, and ethical fields. MHC is new hope for nurses in the field of care and supports holistic care. Table 1 shows the curative processes of Watson's MHC [13].

Table 1. Watson's Caritas Process [13]

\begin{tabular}{ll}
\hline Carative factors & Caritas processes \\
\hline $\begin{array}{l}\text { 1. Humanistic-altruistic system of values. Practicing loving- } \\
\text { kindness/compassion and equanimity for self/other. }\end{array}$ & $\begin{array}{l}\text { Practicing loving-kindness/compassion and equanimity for } \\
\text { self/other. }\end{array}$ \\
\hline 2. Enabling faith-hope & $\begin{array}{l}\text { Being authentically present; enabling belief system and } \\
\text { subjective world of self/other }\end{array}$ \\
\hline 3. Cultivation of sensitivity to self and others & $\begin{array}{l}\text { Cultivating own spiritual practices; beyond ego-self to the } \\
\text { authentic transpersonal presence }\end{array}$ \\
\hline 4. Helping-trusting, human care relationship Sustaining a a & $\begin{array}{l}\text { Sustaining a loving, trusting, and caring relationship. } \\
\text { loving, trusting, and caring relationship. }\end{array}$ \\
\hline 5. Expression of positive and negative feelings & $\begin{array}{l}\text { Allowing for expression of feelings; authentically listening } \\
\text { and "holding another person's story for them", }\end{array}$ \\
\hline 6. The creative problem-solving caring process & $\begin{array}{l}\text { Creatively solution-seeking through the caring process, full } \\
\text { use of self; all ways of knowing/doing/being; engage in the } \\
\text { artistry of human caring healing practices and modalities }\end{array}$ \\
\hline 7. Transpersonal teaching-learning. & $\begin{array}{l}\text { Authentic teaching-learning within the context of a caring } \\
\text { relationship; stay within other's frame of reference, shift } \\
\text { toward a health-healing wellness coaching model }\end{array}$ \\
\hline
\end{tabular}


Table 1. Continued

\begin{tabular}{ll}
\hline Carative factors & Caritas processes \\
\hline $\begin{array}{l}\text { 8. Supportive, protective, and/or corrective mental, social, } \\
\text { spiritual environment. }\end{array}$ & $\begin{array}{l}\text { Creating a healing environment at all levels; physical, } \\
\text { nonphysical, subtle environment of energy and } \\
\text { consciousness, wholeness, beauty, dignity, and peace are } \\
\text { potentiated. }\end{array}$ \\
\hline $\begin{array}{l}\text { Reverentially and respectfully assisting with basic needs, } \\
\text { holding an intentional, caring consciousness of touching }\end{array}$ \\
$\begin{array}{l}\text { the embodied spirit of another as a sacred practice, working } \\
\text { with life force/life energy/life mystery of another. }\end{array}$ \\
$\begin{array}{l}\text { Opening and attending to spiritual, mysterious, unknown, } \\
\text { and existential dimensions of all the vicissitudes of life } \\
\text { change; "allowing for a miracle." All of this is presupposed } \\
\text { by a knowledge base and clinical competence. }\end{array}$ \\
\hline
\end{tabular}

\section{Case Report}

The female patient MA is 55 years old, married, and three children. MA applied to a university hospital with complaints of chills, shivering, and $38.8{ }^{\circ} \mathrm{C}$ fever on 14.04.2020. As a result of the anamnesis it was found that she did not have a sore throat, runny nose, or diarrhea, she had not traveled abroad, she had not contacted any SARS-CoV-2 positive patients, she had not gone to Umrah, she was not smoking, she had muscle and joint pain, she was a hypertension patient, and she had undergone appendectomy and cesarean surgery.

As a result of the computed tomography, a frosted glass image was observed on the peripheral regions of both lungs. The findings were found to be significant in terms of COVID 19 pneumonia. As a result of these findings, the patient was hospitalized in the Covid-19-bed service. Physical examination showed findings of a rally in the lung and the oropharynx was found to have a natural appearance. Blood examination results of the patient were: $\mathrm{CRP}=82$, Sedimentation $=62$, and the patient was ordered azithromycin flk $(1 \times 500 \mathrm{mg})$ and Plaquenil tb $(1 \times 250 \mathrm{mg})$ as treatment. The patient's antibiotic therapy was continued for 5 days and during this period, it was found that the patient's general condition was good, she had complaints of weakness and headache but no fever. The patient's SARS-CoV-2 test was found to be positive. As a result of the blood gas taken, it was found that $\mathrm{pO} 2=34.1 \mathrm{mmHg}$; $\mathrm{HCO} 3=$ $26.5 \mathrm{mEq} / \mathrm{L} ;$ oxyhemoglobin $=57.7 \mathrm{gm} / \mathrm{dL} ; \mathrm{tHb}=9.1 ; \mathrm{CRP}=70.9 \mathrm{mg} / \mathrm{L} ;$ Sedimentation $=79 \mathrm{~mm} / \mathrm{time} .5-$ day-long antibiotic treatment of the patient, whose general condition was good and who did not have a fever, was discontinued. The patient participating in the study were informed about the research and their verbal and written consent was obtained for participation. The patient who agreed to participate in the study were told that the personal information they provided in accordance with the principle of confidentiality would not be disclosed to anyone by the researcher and this information would not be disclosed to third parties. 


\subsection{Evaluation of the Case According to Model of Human Caring Establishing Interpersonal Care Relationship and Starting the Moment of Care}

MA was approached in a warm, sincere, assuring, and the sensitive way during this difficult period she experienced, she was told that we were there for her and as a result, the patient revealed her feelings such as anxiety, fear of death, hopelessness, sadness, and stress. Nursing interventions were planned, and her care was supported accordingly due to the loneliness, desperation, and fear of death the patient experienced during the process of quarantine as a result of the disease.

\subsection{Nursing Interventions Practiced on the Patient According to the Stages of the Model}

\subsubsection{Using the Healing Processes}

\section{Healing Process-1. Humanistic -altruistic system of values.}

The humanistic system of values is based on adopting values such as humanity and devotion and approaching the individual and self with love and affection [13]. It is based on the experiences of the individual including mutual communication and interaction. The patient was called by her name, she was told that we were there for her and an environment full of trust was created. She was approached with sincerity, patience, kindness, understanding, and love while her anamnesis was taken. The patient stated that the approach with love and compassion motivated her [13].

\section{Healing Process -2. Enabling faith-hope}

This process includes instilling faith and hope in the individual. It aims to understand the individual spiritually and to integrate the concepts of faith and hope with mind-body-spirit [13]. Eye connection was established during communication with the patient, effective communication was established, and the patient was encouraged to express her anxiety, fear, sadness, feelings, and thoughts. The patient stated that she would be more positive about the thoughts that had a negative influence on her, she would believe in herself, and that she wanted to recover.

\section{Healing Process -3. Cultivation of sensitivity to self and others}

This process aims to be sensitive to self and others by developing individual beliefs and practices [13]. Understanding and helping the individual can be shown as an example of behaviours showing sensitivity. Nurses should try to understand patients' feelings and thoughts by connecting with their emotional world. The patient was approached without prejudices and her feelings and thoughts about her disease were learned and her incorrect information, attitudes, and beliefs were eliminated. She was informed about the issues she wanted to learn about her disease.

\section{Healing Process - 4. Helping-trusting, human care relationship}

It is a process that aims to develop the relationship between supporting and reassuring care, which forms the basis of quality care, enables explaining positive and negative feelings, and expresses the subjective transition of two people [13]. It includes concepts such as effective communication, empathy, harmony, and sincerity [11-14-15]. the patient was allowed to express herself; she was informed about her disease and her worries and fears were eliminated. MA, who had difficulties in carrying out her daily activities due to her weakness, muscle, and joint pain, was supported on these. The patient stated that she felt better thanks to interventions and that she would contribute more to care.

\section{Healing Process - 5. Expression of positive and negative feelings}

It is the healing process that includes encouraging the individual to express fears and feelings by listening sincerely. Listening to patients and sharing their feelings has a great significance in the process 
of healing for nurses [13]. MA was encouraged to express her fears, worries, and sadness. It was found that in time the patient was able to share her positive and negative feelings more comfortably as a result of the reassuring environment.

\section{Healing Process - 6. The creative problem-solving caring process}

It includes using creative, scientific problem-solving methods to decide on the care and scientific problem-solving ways based on science and practice [13]. The patients' nursing interventions were planned and practiced according to the patient's disease symptoms. Measures were taken for the risk of falling during the quarantine. The patient was made to rest for her pain and weakness. It was found that the patient felt better after the interventions.

\section{Healing Process - 7. Transpersonal teaching-learning.}

This process is based on providing learning and teaching suitable for individual needs and comprehension styles, enabling the individual to take part in self-care and also individualized care [13]. The patient was informed about important hygiene applications and observed. In order to strengthen the immune system, a balanced and healthy diet was provided and a diet program suitable for the patient was provided. In this period, an increase was seen in the patient's trust in the nurse.

Healing Process -8. Supportive, protective, and/or corrective mental, social, spiritual environment

It is a process that aims to create a physically, emotionally, and spiritually comfortable, nice, peaceful environment, to provide quality care and healing, to improve health, and to prevent diseases [13]. A physically and mentally healthy environment in which the patient could feel comfortable under the quarantine was created. The nurse tried to remove the prejudices of the patient who did not like the hospital environment. During joint pain, the non-pharmacological method was applied by drawing the patient's attention in another direction. After the patient was discharged, she was supported by being informed about home care.

\section{Healing Process -9. Human needs assistance}

It is a process that helps the physical, emotional, and mental needs of the patient and a process in which all needs are important and correlated with each other at the moment of care [13]. The issues the individual needed help with during this process were determined and the patient was helped to participate in self-care. Care was taken for the patient to have an adequate and balanced diet, to pay attention to oral care after meals, and to pay attention to hand hygiene and general hygienic rules. The patient was given psychological support and thus enabled her to share her feelings and thoughts. The patient stated that she wanted to participate more in care and that she would be more effective in dealing with the disease.

\section{Healing Process -10. Existential-phenomenological-Spiritual forces}

It is a process that reveals the real meaning of life (dream, intuition, legend), enables the individual to understand self and others, and gives a mysterious and philosophical perspective to human experiences. The nurse tries to make the patient understand life/disease and death [13]. Effective communication was built with the patient and the patient was encouraged to express herself about the difficulty of the situation she was in. In this process, the goals of care are spiritual support, gaining selfconfidence, and reassurance [11-14-15]. When all the healing processes were applied, it was found that the patient felt better and her fears and worries decreased. 


\section{Conclusion}

Watson's Theory of Human Caring is a model that includes a great number of concepts (such as compassion, love, trust, respect, human) and which has been used in the care of chronic diseases for many years. The model constitutes the core of nursing in reducing the negative feelings caused by the disease symptoms, in the process of coping with the disease and adapting to the disease. The healing processes used in the model give a new perspective to the methods and practices in nursing in increasing patient satisfaction, giving spiritual and holistic care. In this case study, positive changes were observed in the patient, and coping and adopting the process was supported based on the model of human caring and healing processes.

Conflict of Interest: No conflict of interest was declared by the authors.

Financial Disclosure: The authors declared that this study has received no financial support.

Ethics Statement: The study was carried out in line with the principles of the Helsinki Declaration. Approval was received for this study from the patient.

Ethics Committee's Name, approval number, and date: Erzincan Binali Y1ldırım University / Human Research Ethics Committee Decision. (Date: 30/06/2020, Number: 06/19).

Information about the volunteer informed/consent form: In this study, the consent forms have been signed by volunteers.

The compliance to the Research and Publication Ethics: This study was carried out in accordance with the rules of research and publication ethics.

\section{References}

[1] Chen, H., Guo, J., Wang, C., Luo, F., Yu, X., Zhang, W., Li, J., Zhao, D., Xu, D., Gong, O., Liao, J., Yang, H., Hou, W., Zhang, Y, "Clinical characteristics and intrauterine vertical transmission potential of COVID-19 infection in nine pregnant women: a retrospective review of medical records," - e Lancet, 395(10226), 809-15, 2020.

[2] WHO, Coronavirus disease (COVID-19) situation reports, 2020. https://www.who.int/docs/default-source/coronaviruse/situation reports/20200414-sitrep-85COVID-19.pdf?sfvrsn=7b8629bb 4

[3] Wu, D., Wu, T., Liu, Q., Yang, Z, “The SARS-CoV-2 outbreak: what we know", Int J Infect Dis, 94, 44-48, 2020.

[4] Sağl1k Bakanlığı. Türkiye' deki güncel durum, https://covid19.saglik.gov.tr/

[5] CDC, Coronavirus Disease 2019 (COVID-19), Stress and Coping https://www.cdc.gov/coronavirus/2019-ncov/daily-life-coping/managing-stress-anxiety.html

[6] WHO, Mental health \& COVID-19, https://www.who.int/teams/mental-health-and-substance$\underline{\text { use/covid-19 }}$ 
[7] Üstün, Ç., Özçiftçi, S., "COVID-19 Pandemisinin Sosyal Yaşam ve Etik Düzlem Üzerine Etkileri: Bir Değerlendirme Çalışması,” Anadolu Klinikleri. 25(1), 142-53, 2020.

[8] Mental Health Guide during COVID -19 Pandemic Period (Coping with Stress and StressRelated Symptoms), https://panel.kku.edu.tr/Content/Anasayfa/AcilisDuyuru/1/covid1914nisan2020.pdf

[9] Seker, M., Ozer, A., Tosun, Z., Korkut, C., Dogrul, M, Covid-19 Pandemi Değerlendirme Raporu, Türkiye Bilimler Akademisi Yayınları, Report No. 20, Ankara, 2020.

[10] Fawcett, J., Watson's theory of human care, In Fawcett J, editor. Contemporary nursing knowledge analysis and evaluation of nursing models and theories. Philadelphia: F.A. Davis Company, pp.553-99, 2006.

[11] Aktürk, Ü., Kemoterapi Alan Hastalara Watson İnsan Bakım Modeline Göre Verilen Bakımın Yaşamın Anlamı ve Semptom Yönetimine Etkisi. Doktora Tezi. İnönü Üniversitesi Sağlık Bilimleri Enstitüsü. Malatya, 2016.

[12] Karadăg, A., Çalışkan, N., Baykara, Z.G., Hemşirelik Teorileri ve Modelleri, Akademi Basın ve Yayınc1lık., İstanbul, 2017.

[13] Watson, J., Human Caring Science: A Theory of Nursing, 2nd ed. Sudbury: MA: Jones \& Bartlett Learning, pp.75-85, 2012.

[14] Erbay, Ö., Yıldırım, Y., Fadıloğlu, Ç., Aykar, F.Ş., "Hipertansif Atak Yaşayan Hastalara Watson'ın İnsan Bakım Modeli Kullanılarak Uygulanan Hemşirelik Bakımı: Olgu Sunumu," Kardiyovasküler Hemşirelik Dergisi. 9(19), 82-8, 2018.

[15] Uran, B.N.Ö., Özer, S., Yıldırım, Y., "Watson İnsan Bakım Modeli Uygulamasına Bir Örnek: Kalp Yetersizliği Olgusu,” Kardiyovasküler Hemşirelik Dergisi, 6(11), 183-98,2015. 